\title{
Pass på fingeren
}

I Tidsskriftet nr. 8/1926 (Tidsskr Nor Lægeforen 1926; 46: 384-6) hadde legevaktlege Otto Holmboe et innlegg om hvordan skadede fingre kunne beskyttes for å unngå sykmeldinger. For også den gang hadde legen et samfunnsøkonomisk ansvar.

\section{Stiv fingerbeskytter.}

\author{
av Otto Holmboe, Oslo.
}

Fingerskader er en av de hyppigste aarsaker til hel eller delvis arbeidsudygtighet. Ofte kan skaden være saa liten, at lægen ærgrer sig over at maatte sykmelde; men har man ikke andet end en hanskesmokk eller en bløt lærsmokk at beskytte den skadede finger med, blir resultatet i almindelighet, at patientens krav paa at sykmeldes blir tat til følge.

Som assistentlæge ved Oslo kommunale lægevaktstation har jeg i flere aar arbeidet for at finde en maate at beskytte skadede fingre paa slik, at sykmelding kan undgaaes eller arbeidsudyktigheten forkortes.

Efter at ha prøvet en række bløte, halvstive og stive fingersmokker er det endelige resultat blit en stiv fingerbeskytter, som jeg mener fortjener at bli kjendt og benyttet av lægerne.

Det er nemlig ingen tvil om, at man ved denne, som vi nu i flere aar i stadig stigende utstrækning har benyttet paa lægevaktstationen, kan undgaa resp. forkorte arbeidsudygtigheten ved fingerskader i en grad, som vil spille en ikke ubetydelig økonomisk rolle, hvis bruken av den stive fingerbeskytter blir almindelig i det hele land.

Fingerbeskytteren lages av lær, som ikke er helt gjennemgarvet, men har en «raa rand» i midten. Denne tilberedning av læret gjør, at fingerbeskytteren blir meget haard og motstandsdygtig. Ved beisning (lakering) utvendig og indvendig gjøres den ugjennemtrængelig for vand, og derved meget holdbar.

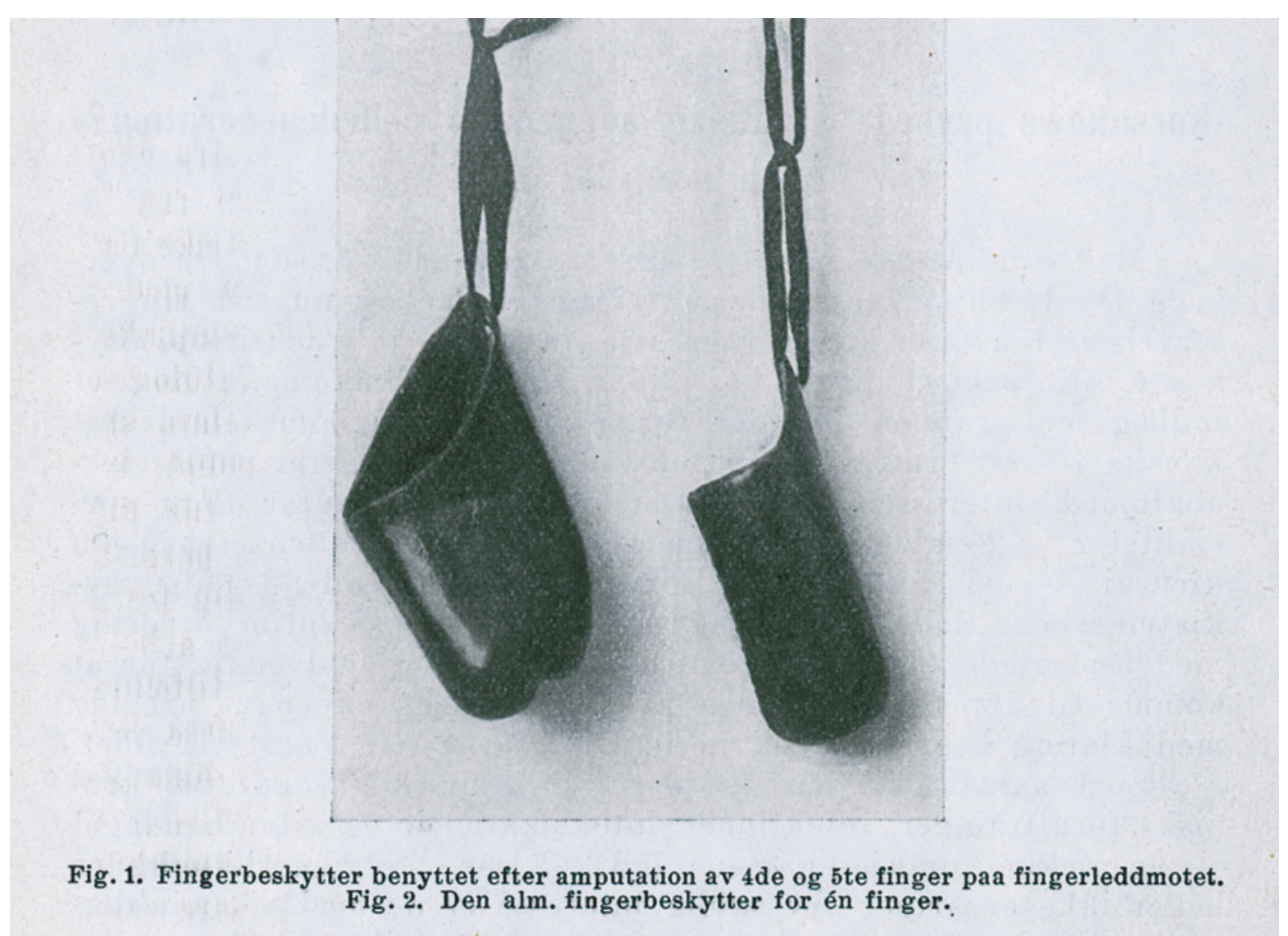

(...) Er beskytteren riktig lagt, kan den skadede i almindelighet utføre sit arbeide selv med ret betydelige fingerskader som saar, nylig utførte amputationer og reponerte luksationer og enkelte frakturer. 